\title{
Ryszard Dziura, Dialog z religijno-społeczną tradycją ludów Zambii w świetle posoborowej nauki Kościoła, Wydawnictwo KUL, Lublin 2009, 318 s.
}

Tematyka prezentowanej książki jest dość rzadko poruszana w polskim piśmiennictwie teologicznym. Dotyczy Kościoła katolickiego w Afryce, ze szczegółowym omówieniem historii Kościoła w Zambii na tle rodzimych tradycji religijnych.

Autor skomponował dzieło z 8 rozdziałów ułożonych w porządku retrospektywnym - najpierw przedstawił obecny stan religijności Zambijczyków, by następnie odkrywać tradycyjne wierzenia i ich nieustanny wpływ na moralność i obyczajowość, a nawet liturgię katolicką.

Rozdział 1. dotyczy ewangelizacji Zambii i obecnej roli Kościoła katolickiego (s. 27-69). Obejmuje historię Kościoła w Zambii, począwszy od pierwszych kontaktów z chrześcijaństwem pod koniec XIX wieku do pierwszego dziesięciolecia XXI wieku. Uświadomił przy tym zbieżność dwóch procesów przeprowadzonych przez Brytyjczyków na części kontynentu afrykańskiego - kolonizacji i chrystianizacji. Zdumiewa podana przez Misjonarza ilość anglikańskich misjonarzy chrystianizujących pod koniec XIX wieku teren dzisiejszej Zambii, sięgająca ok. 12000 osób. Do nich dołączyli misjonarze katoliccy i przedstawiciele innych wyznań chrześcijańskich, rozpoczynając dialog międzyreligijny na terenie misyjnym. W sposób przejrzysty, z zachowaniem chronologii, stosując jednak cezury czasowe ważne dla Europejczyka, przedstawił rozwój misji do roku 1900 (s. 29-32), od 1900 do pierwszej wojny światowej (s. 32-34), od pierwszej wojny światowej do 1939 roku (s. 34-39), od drugiej wojny światowej do wyzwolenia kraju się spod zależności kolonialnej w 1964 roku (s. 39-44), przedstawił kondycję Kościoła katolickiego w niepodległej Zambii (s. 44-62), by przejść do jego wyzwań społecznych, jak troska o naród i państwo (s. 6266) oraz pomoc dotkniętym chorobą AIDS (s. 66-68). Rozdział 1., dotyczący początku okresu misji katolickich, wbrew pozorom ukazuje nie tyle Kościół na terenie dzisiejszej Zambii, co charakteryzuje cały Kościół powszechny, zabiegający o szerzenie chrześcijaństwa w świecie, przedstawia jego kondycje i dynamizm rozwoju instytucji predestynowanych do pracy misyjnej, jak liczne zgromadzenia zakonne, także rodzime - afrykańskie, czy instytucje opiekuńcze, w tym lecznicze.

Współistnieniu misjonarzy chrześcijańskich, przynależących do różnych konfesji i dialogowi z wyznawcami rodzimych religii afrykańskich w duchu postanowień Soboru Watykańskiego II oraz chrześcijańskiej inkulturacji po- 
święcił ks. Dziura rozdział 2. (s. 69-131). Przedstawił w nim nauczanie i sposób nawiązywania relacji z religijną ludnością Zambii posoborowych papieży Pawła VI i Jana Pawła II. Szczególny nacisk położył na Zgromadzenie Synodu Biskupów poświęcony Afryce (s. 112-127) i posynodalną adhortację papieża Jana Pawła II Ecclesia in Africa (s. 127-130). Ponadto omówił wszystkie dokumenty Stolicy Apostolskiej dotyczące chrystianizacji, inkulturacji Kościoła i dialogu religijnego w Zambii.

Realia misji chrześcijańskich w Zambii omówił w rozdziale 3., przedstawiając podstawy światopoglądu Afrykanów wierzących w Istotę Najwyższą, Stwórcę i Ojca całego stworzenia oraz w istnienie i współistnienie świata niewidzialnego i widzialnego oraz hierarchię bytów (s. 131). Ukazał integrującą rolę rodzimego światopoglądu religijnego, zwracając uwagę na głęboki związek aktów religijnych z życiem, co określa sposób przeżywania przyjmowanej wiary chrześcijańskiej z równoczesnym przywiązaniem do wierzeń tradycyjnych (s. 136). Szczegółowy wykład Autora o Istocie Najwyższej - transcendentnej i immanentnej oraz o niekwestionowanym wierzeniu w Nią przez Afrykanów pozwala zapoznać się z "gruntem” religijnym, na który jest wszczepiane chrześcijaństwo (s. 137-153). $\mathrm{Z}$ podziwem należy podkreślić pieczołowitość przedstawiania różnic wierzeniowych poszczególnych ludów - Bemba i Lala (s. 147-149), Ambo, Lamba i Kaonde (s. 149-150), Tonga (s. 150-151), Lozi (s. 151-153).

$\mathrm{W}$ rozdziale 4 . kontynuował Autor charakterystykę tradycyjnej religijności, wiele uwagi poświęcając kultowi przodków, z uwzględnieniem różnic charakterystycznych dla poszczególnych ludów Zambii (s. 155-174) i ich eschatologii (s. 174-184).

Rozdział 5. poświęcił omówieniu tradycyjnej moralności (s. 203-208), tradycyjnych wartości społecznych i moralnych Zambijczyków, z wyakcentowaniem ich postawy wobec życia (s. 185-192), małżeństwa i rodziny z uwzględnieniem wskazań Specjalnego Zgromadzenia Synodu Biskupów poświęconego Afryce (s. 192-203).

Rytuały w tradycji zambijskiej społeczności patrylinearnych i matrylinearnych omówił Autor w rozdziale 6., akcentując podobieństwa i różnice w rytuałach związanych z małżeństwem i rodziną (s. 209-231). Opisał też rytuały doroczne (s. 232-234) oraz kryzysowe i uzdrowicielskie (s. 234-238), tym ostatnim poświęcając również cały rozdział 7. (s. 239-254) i zamieszczając stanowisko Kościoła wobec magii i czarów (s. 248-250).

Rozdział 8. (s. 255-268), mówiący o inkulturacji w Kościele zambijskim, potraktował Autor jako podsumowanie działań misyjnych chrześcijańskich, które doprowadziły do ukształtowania tam Kościoła katolickiego ze specyficznymi cechami afrykańskimi, widocznymi zwłaszcza w liturgii ubogaconej tradycyjnymi melodiami i rytmami. 
Należy zaznaczyć, że ks. Dziura spełnił założenia wymienione we Wstępie (s. 15-25) - przybliżył polskiemu czytelnikowi obraz Kościoła katolickiego w Zambii, ubogacając go charakterystyką tradycyjnej kultury i religijności ludów afrykańskich. Spełnił też cel naukowy - przedstawił proces chrystianizacji 9 ludów afrykańskich mieszkających na terenie Zambii i udokumentował zaangażowanie weń Stolicy Apostolskiej. Podał bogaty warsztat naukowy w postaci źródeł - dokumentów papieskich, soborowych, dykasterii rzymskich, Specjalnego Zgromadzenia Synodu Biskupów poświęconego Afryce i Konferencji Episkopatu Zambii (s. -284). Zamieścił też literaturę przedmiotową w postaci opracowań i wywiadów (s. 285-291) oraz bogatą literaturę pomocniczą (s. 291-296).

Książka posiada spis treści w języku polskim i angielskim oraz Summary w języku angielskim (s. 297-304), co może sprzyjać zainteresowaniu się nią przez czytelnika nieznającego języka polskiego. Ponadto wyposażona jest w Indeks osób (s. 305-307 i Indeks nazw (s. 309-318), stając się swoistym słownikiem pojęć afrykologicznych. Ponadto po rozdziale 1. i 2. książki umieścił Autor mapki obrazującą topografię obszaru Zambii (s. 69) i jego etnografię (s. 131).

Książka Dialog z religijno-społeczną tradycją ludów Zambii w świetle posoborowej nauki Kościoła powstała w wyniku wieloletnich studiów Autora i osobistego dziesięcioletniego doświadczenia misyjnego w Zambii (w latach 1985-1994). Napisana jest pięknym zwartym stylem encyklopedycznym, co stało się odbiciem wieloletniej pracy ks. Ryszarda Dziury w Redakcji Encyklopedii Katolickiej KUL (od 1995 roku) i autorstwu haseł encyklopedycznych dotyczących Afryki w Encyklopedii biatych plam (Radom 2000-2006, t. I-XX), Wielkiej ilustrowanej encyklopedii powszechnej (Warszawa 1997-2003, t. I-XXIV ) oraz dotyczących misji katolickich i religii niechrześcijańskich w Encyklopedii Katolickiej KUL (Lublin 1997-2010, t. VII-XIV). Nie dziwi więc, że autonomiczne dzieło Autora, które mam honor i przyjemność charakteryzować, osiągnęło dojrzałość zarówno w zakresie merytorycznego opracowania, jak też przygotowania redaktorskiego. Warto po nią sięgnąć wszystkim zainteresowanym powszechnością Kościoła katolickiego, wciąż rozwijającego się w rejonach, gdzie musi zdobywać wiernych dotkniętych niezwykłym ubóstwem i przywiązanych do tradycyjnych wierzeń.

Zofia Pałubska Instytut Leksykografii KUL 